5. Gerberding JL, Bryant CE, Newman M, et al: Risk of acquired immune deficiency syndrome (AIDS) virus transmission to health care workers (HCW): Preliminary follow-up. Clin Res 1986; 34:101A.

6. Henderson DK, Saah AJ, Zak BJ, et al: Risk of nosocomial infection with human $T$ cell lymphotropic virus type III/lymphadenopathy-associated virus in a large cohort of intensively exposed health care workers. Ann Intern Med 1986; 104:644-647.

7. Michaelis BA, Levy JA: Recovery of human immunodeficiency virus from serum, letter. JAMA 1987 ; 257:1327.

8. Shikata T, Karasawa T, Abe K, et al: Hepatitis B e antigen and infectivity of hepatitis $B$ virus. J Infect Dis 1977; 136:571-576.

Larry M. Baddour, MD Assistant Professor of Medicine Department of Medicine

Division of Infectious Diseases University of Tennessee, Memphis Memphis, Tennessee

\section{Infection Control Practitioners and AIDS}

\section{To the Editor:}

Infection control practitioners across the country are experiencing a crisis, particularly if they are located in large metropolitan hospitals. However, the eventual outcome of this crisis is potentially the same for all practitioners, regardless of hospital location. Now is the time for assessing our needs and acknowledging the support systems required to meet the challenge of the AIDS crisis in our hospitals in an effort to plan for the future.

Unfortunately, hospital administrators are suffering a similar crisis concomitantly. Fiscal restraints become increasingly pervasive each year, as we all know, and human immunodeficiency virus (HIV) infection does not generate revenue. Nonetheless, we are looking to our administrators for necessary support for additional educational funding and "person power" to meet the needs of effectively facing this epidemic in our everyday work experience.

Therefore, the struggle to balance an already, oftentimes, demanding profession with the impact of this epidemic is voiced as frustrating and burdensome by many of us. Our ability to communicate the required support systems is often inadequate.

Creative solutions are needed. The need to continue nosocomial surveillance programs, and meet the other needs we are all so familiar with in our hospitals is being greatly outweighed by this slow, insidious, progressive epidemic.

Please acknowledge that support is required by our own organization, as well as by the Centers for Disease Control. An improved system to realistically assess the need for infection control personnel based on bed occupancy, acuity, and size of the population with HIV infection being treated is needed. "One practitioner for every two hundred and fifty beds" is now archaic, therefore, no longer applicable. It is actually self-defeating.

The challenge is before us to respond, voice our professional needs, and responsibly represent ourselves to the hospital communities at large. Our lack of problem assessment will only continue to foster the chaos pervading this period of the AIDS crisis.

\section{Terri Rearick, RN Nurse Epidemiologist The Children's Memorial Hospital Chicago, Illinois}

Letters to the Editor should be addressed to INFECTION CONTROL Editorial Offices, C4I General Hospital, University of Iowa Hospitals and Clinics, Iowa City, IA 52242. All letters must be typed double spaced and may not exceed four pages nor include more than one figure or table. The editors reserve the right to edit for purposes of clarity or brevity.
This publication is available in microform.

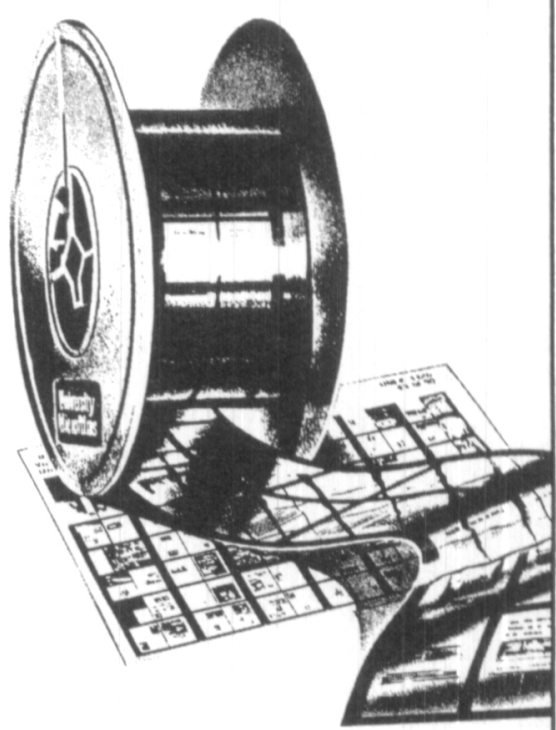

University Microfilms International reproduces this publication in microform: microfiche and $16 \mathrm{~mm}$ or $35 \mathrm{~mm}$ film. For information about this publication or any of the more than 13,000 titles we offer, complete and mail the coupon to: University Microfilms International, $300 \mathrm{~N}$. Zeeb Road, Ann Arbor, MI 48106. Call us toll-free for an immediate response: 800-521-3044. Or call collect in Michigan, Alaska and Hawaii: 313-761-4700.

$\square$ Please send information about these titles:

Name

Company/Institution

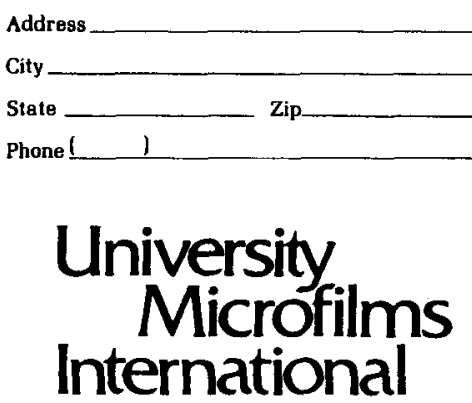

